Jurnal Penelitian dan Pengabdian Kepada Masyarakat Bidang ilmu Pendidikan

\title{
Peran Guru Sebagai Fasilitator dalam Mengasah Penalaran Matematika Siswa SDN 29 Dompu Tahun Pembelajaran 2020/2021
}

\author{
Ija Srirahmawati \\ Dosen Program Studi Pendidikan Guru Sekolah Dasar, STKIP Yapis Dompu \\ E-mail: ijasrirahmawati94@gmail.com
}

Article History: Received: 2021-01-05 || Revised: 2021-02-15 || Published: 2021-03-31

Sejarah Artikel : Diterima: 2021-01-05 || Direvisi: 2021-02-15 || Dipublikasi: 2021-03-31

\begin{abstract}
The teacher acts as an educator and acts as a facilitator. The facilitator plays an important role in the learning process. In terms of facilitating the teacher must be precise and interesting. Mathematical reasoning is a process of thinking in drawing conclusions to find out and be able to solve problems, which is the target of this study, which is to find out the role of the teacher as a facilitator in honing mathematical reasoning for SD Negeri 29 Dompu students in 2020/2021 Learning Year. The data analysis method used is a descriptive qualitative analysis method. Data sources in this study were teachers and fourth grade students of SD Negeri 29 Dompu. Data were collected using observation and interview techniques. The data obtained were then analyzed by data reduction, data presentation, and data verification. This study concludes that the teacher's task as a facilitator is very important to increase student confidence. The role of the teacher as a facilitator in learning mathematics is very influential in increasing motivation, fostering curiosity, and increasing students' interest in learning about mathematical reasoning examples $3+5=8$, so students reason that odd numbers when added to different odd numbers result in even numbers.
\end{abstract}

Keywords: The Role of Teachers, Facilitators, Mathematical Reasoning

\begin{abstract}
Abstrak
Guru bertindak sebagai pendidik dan berperan sebagai fasilitator. Fasilitator berperan penting dalam proses pembelajaran. Dalam hal memfasilitasi guru harus tepat dan menarik. Penalaran matematika merupakan proses berpikir dalam menarik kesimpulan untuk mengetahui dan dapat memecahkan masalah, yang menjadi sasaran penelitian ini yaitu untuk mengetahui peran guru sebagai fasilitator dalam mengasah penalaran matematika siswa SD Negeri 29 Dompu Tahun Pembelajaran 2020/2021. Metode analisis data yang digunakan adalah metode analisis deskriptif kualitatif. Sumber data dalam penelitian ini adalah guru dan peserta didik kelas IV SD Negeri 29 Dompu. Data dikumpulkan menggunakan teknik observasi dan teknik wawancara. Data yang diperoleh kemudian dianalisis dengan reduksi data, penyajian data, dan verifikasi data. Penelitian ini menyimpulkan bahwa tugas guru sebagai fasilitator sangat penting untuk meningkatkan rasa percaya diri siswa. Peran guru sebagai fasilitator dalam pembelajaran matematika sangat berpengaruh dalam meningkatkan motivasi, menumbuhkan keingintahuan, dan meningkatkan minat belajar pada siswa terhadap penalaran matematika contoh $3+5=8$, jadi siswa menalar bahwa angka ganjil jika dijumlahkan dengan angka ganjil yang berbeda maka menghasilkan angka genap.
\end{abstract}

Kata kunci: Peran Guru, Fasilitator, Penalaran Matematika

\section{PENDAHULUAN}

Guru memiliki peranan yang sangat penting dalam keberhasilan proses pembelajaran. Keberhasilan seorang guru dalam proses pembelajaran dapat dilihat dari tercapainya tujuan pembelajaran. Salah satu tercapainya tujuan pembelajaran adalah siswa dapat memahami dan mengerti mengenai materi yang disampaikan oleh guru. Dalam keseluruhan proses pendidikan di sekolah kegiatan belajar mengajar merupakan kegiatan yang paling pokok. Keberhasilan pencapaian dari tujuan pendidikan terutama ditentukan oleh bagaimana proses belajar mengajar yang dialami siswa. Siswa yang belajar tentu akan mengalami sesuatu perubahan baik perubahan dalam pengetahuan, pemahaman, keterampilan, nilai dan sikap. Guru sebagai orang yang dianggap 
memiliki kemampuan untuk mentransfer pengetahuan kepada siswa diharapkan mampu mengemban tugas secara profesional sesuai dengan disiplin ilmu yang dimilikinya (Esi et al., 2016).

Guru sebagai fasilitator harus memiliki sikap yang baik, pemahaman terhadap peserta didik melalui kegiatan dalam pembelajaran dan memiliki kompetensi dalam menyikapi perbedaan individual peserta didik Mulyasa (2013:55-57). Tugas guru adalah membantu siswa yang mengalami kesulitan dalam memahami materi pelajaran, untuk itu guru sebagai fasilitator mendorong siswa untuk aktif mengikuti pelajaran yang berlangsung, sehingga siswa mampu memecahkan masalah tersebut demi masa depan mereka sendiri (Wijaya dkk, 2014: 34). Dalam setiap proses pembelajaran siswa seharusnya berperan aktif dalam proses pembelajaran. "Guru hanya memfasilitasi bagaimana proses "learning by doing" itu dilaksanakan, dengan cara ini diharapkan siswa termotivasi untuk mengaktulasisasi potensi siswa secara optimal” (Wijaya dkk, 2014: 30). Guru hanya mengarahkan proses belajar siswa disaat siswa sedang mengalami kesalahan dalam mengaktualisasikan pikirannya, inilah harapan supaya pembelajaran siswa aktif dengan sendirinya.

Pembelajaran yang aktif (Hakim, 2008: 54) adalah "kegiatan pembelajaran yang memberikan kesempatan kepada siswa untuk berinteraksi dengan mata pelajaran yang dipelajari”. Siswa lebih aktif mempelajari materi pembelajaran yang membuat mereka mampu untuk hidup, informasi yang diterima lebih lama diingat dan disimpan, dan lebih menikmati suasana kelas yang nyaman. Siswa dapat mengemukakan pendapat atau pandangannya, Tanya jawab, mampu mengembangkan terkait dengan ilmu pengetahuan, memecahkan masalah, diskusi, dan menarik sebuah kesimpulan. Peran guru tidak dominan menguasai proses pembelajaran melainkan memberikan kemudahan (fasilitator). Pada saat mengajar guru dihadapkan pada persoalan-persoalan yang berkaitan dengan bagaimana cara guru mempermudah belajar siswa. Guru diupayakan perlu memberi kemudahan dalam menyampaikan informasi. Siswa yang memperoleh kemudahan dalam menerima informasi akan belajar dengan lebih bersemangat dan termotivasi. Dengan kata lain siswa belajar dengan aktif dengan sendirinya tanpa menunggu perintah dari guru. Kegiatan pembelajaran aktif antara lain, tanya jawab, diskusi dan inkuiri.

Kemampuan penalaran matematis adalah salah satu kemampuan berpikir yang perlu dikembangkan. Kemampuan ini mendukung untuk mengasah kemampuan pemecahan masalah matematis, kemampuan koneksi matematis dan kemampuan matematika lainnya (Pamungkas \& Yuhana, 2016). Kemampuan bernalar adalah proses mental yang terjadi dalam diri individu ketika mengembangkan pikiran pada saat menghadapi beberapa kasus atau permasalahan. Selain pengertian tersebut, Keraf (Pamungkas \& Yuhana, 2016) menyatakan bahwa penalaran sebagai proses berpikir yang berusaha menghubung-hubungkan fakta-fakta atau evidensi-evidensi yang diketahui menuju kepada suatu kesimpulan. Dari pengertian tersebut bahwa kemampuan penalaran matematis adalah untuk mengembangkan proses berpikir yang diharapkan mendukung pada kemampuan seseorang untuk memberikan alasan/argumen-argumen dari apa yang dikemukakan dengan cara menghubungkan fakta-fakta yang telah diketahuinya.

Berdasarkan hasil pengamatan diperoleh data bahwa peran guru dalam proses pembelajaran matematika di SD Negeri 29 Dompu masih belum maksimal. Pembelajaran yang dilakukan masih berpusat pada guru, sementara siswa duduk secara pasif menerima informasi pengetahuan. Hal tersebut terlihat dari kurang aktifnya guru menfasilitasi siswa dalam proses pembelajaran yang berlangsung. Proses pembelajaran masih didominasi oleh guru dan sedikit melibatkan siswa, sehingga menyebabkan rendahnya kemampuan bernalar siswa sendiri dalam memecahkan masalah matematis (Observasi pada Rabu, 15 Juni 2020). Dalam hal ini siswa tidak dipandang sebagai objek pembelajaran, tetapi sebagai subjek pembelajaran itu sendiri. 
Berdasarkan uraian latar belakang di atas, maka dipandang perlu untuk meneliti lebih lanjut peran guru sebagai fasilitator dalam mengasah penalaran matematika siswa di SD Negeri 29 Dompu tahun pembelajaran 2020/2021.

\section{METODE PENELITIAN}

Jenis penelitian ini menggunakan pendekatan kualitatif karena bergantung pada pengamatan dan wawancara yang dilakukan peneliti di sekolah, hasil pengamatan tersebut berupa data deskriptif tertulis maupun lisan dari sumber data dalam hal ini guru, siswa, serta kepala sekolah SD Negeri 29 Dompu. Dalam penelitian ini peneliti hadir sebagai pengamat penuh karena peneliti berada diluar situasi yang diamati dan tidak ada hubungan sama sekali antara pengamat dan yang di amati (Sukmadinata, 2008: 111), "sebagai pengamat penuh peneliti perlu melakukan beberapa hal sebagai berikut untuk memudahkan peneliti saat melakukan penelitian. Hal tersebut anatara lain: Mengenal tempat penelitian serta membangun kedekatan yang baik dengan subjek yang di teliti agar memudahkan peneliti memperoleh data saat melakukan penelitian, Mengumpulkan data dan sekaligus menyimpulkan data, Mengecek keabsahan data yang di peroleh di lapangan.

Penelitian ini dilaksanakan di SD Negeri 29 Dompu yang berlokasi di desa O'O kecamatan Dompu kabupaten Dompu. Peneliti memilih lokasi yang menjadi tempat penelitian ini disebabkan bahwa SD Negeri 29 Dompu merupakan salah satu sekolah yang diminati oleh calon siswa baru yang berada di desa $0^{\prime} 0$ dan juga pada sekolah tersebut peran guru sebagai fasilitator belum terlihat secara maksimal. Sekolah tersebut yang beralamat di jalan Lintas Sumbawa O'O Kabupaten Dompu. Sumber data yang digunakan peneliti ini meliputi sumber data primer dan sumber data sekunder. "Sumber primer yaitu data yang diperoleh langsung dari subjek penelitian dengan menggunakan alat pengukuran data atau pengambilan data langsung pada subjek sebagai sumber informasi yang dicari" (Arikunto, 2006: 212). Data sekunder yaitu data yang diperoleh dari pihak lain, tidak langsung diperoleh dari subjek penelitiannya. Data ini berwujud data dokumentasi atau data laporan yang telah tersedia (Sugiyono, 2010: 122). Data sekunder biasanya digunakan sebagai pendukung data primer. Ciri-ciri sumber sekunder adalah tidak berkaitan langsung dengan objek yang diteliti dan tingkat keabsahan datanya satu tingkat di bawah sumber primer

\section{A. Teknik Pengumpulan Data}

Adapun teknik pengumpulan data yang digunakan dalam penelitian ini adalah:

\section{Observasi}

Observasi adalah tehnik pengumpulan data dengan cara mengamati secara langsung objek yang di teliti" (Arikunto, 2006:272). Teknik observasi dalam penelitian ini dilakukan di kelas IV SD Negeri 29 Dompu tahun pembelajaran 2020/2021 pada semester II materi pembelajaran bilangan bulat. Observasi digunakan untuk melihat secara langsung aktifitas guru dan siswa dalam proses pembelajaran.

\section{Wawancara}

Arikunto (2006:211) menyatakan bahwa "metode wawancara adalah metode untuk mencari data yang dilakukan dengan cara bertemu langsung dengan responden atau sumber data". Sedangkan Moleong (2013: 53) mengatakan bahwa "metode wawancara adalah cara pengumpulan data yang dilakukan melalui percakapan antara peneliti (atau orang yang ditugasi) dengan subjek penelitian atau responden atau sumber data". Dalam penelitian ini teknik pengumpulan data wawancara dilakukan setelah pembelajaran selesai, wawancara dengan guru dilakukan dalam kelas begitu juga dengan siswa akan di wawancarai dalam kelas, sedangkan kepala sekolah akan di wawancarai di ruangan kepala sekolah. Wawancara yang digunakan dalam penelitian ini yaitu wawancara terstruktur dengan pedoman wawancara. 


\section{Dokumentasi.}

Dokumentasi, dari asal katanya dokumen yang artinya barang-barang tertulis. "Di dalam melaksanakan metode dokumentasi peneliti menyelidiki benda-benda tertulis seperti buku, majalah, dokumen, peraturan-peraturan, notulen rapat, catatan harian, dan sebagainya" (Arikunto, 2006: 201).

\section{B. Teknik Analisis Data}

Tehnik Analisis Data menurut Sugiyono (2010: 224) "teknis analisis data adalah proses mencarai dan menyususn secara sistematis data yang diperoleh dari hasil wawancara, observasi dan dokumentasi dengan cara mengorganisasikan data kedalam kategori, menjabarkan kedalam unit-unit, menyusun kedalam pola, memilih mana yang penting dan yang akan dipelajari, dan membuat kesimpulan sehingga muda dipahami oleh diri sendiri maupun orang lain". Dalam menganalisis dilakukan kegiatan, mengatur urutan data, mengklasifikasi data sesuai dengan tujuan dan fokus penelitian, metode yang digunakan adalah metode deskriptif kualitatif. Proses analisis data dimulai dengan mengkaji dan menelaah sumber-sumber data, baik dari hasil observasi maupun hasil wawancara yang dilakukan dengan tahap-tahap sebagai berikut:

\section{Data Reduction (Reduksi data)}

Mereduksi data berati merangkum, memilih hal-hal pokok, memfokuskan pada hal-hal yang penting, dicari tema dan polanya" Sugiyono (2010: 21). Dalam hal ini mencatat data yang diperoleh secara teliti supaya data yang telah direduksi akan memberikan gambaran yang jelas, dan mempermuda melakukan pengumpulan data selanjutnya yang dicari dan diperlukan.

\section{Data Display (Penyajian Data)}

Setelah data direduksi, langkah selanjutnya yaitu mendisplay data. Milles dan Huberman (dalam Sugiyono, 2010: 252) menyatakan "dengan mendisplaykan data, maka memudahakan untuk memahami yang akan terjadi, merencanakan selanjutnya, berdasarkan apa yang dipahami tersebut".

\section{Simpulan (Penarikan Simpulan)}

Menurut Milles dan Huberman (Sugiyono, 2010: 253) Menyatakan "langkah ketiga dalam menganalisis data yaitu penarikan simpulan dan verifikasi". Simpulan merupakan penarikan generalisasi dari hasil interpretasi temuan penelitian. Kegiatan ini merupakan langkah terakhir dalam menganalisis data dalam penelitian. Data yang telah direduksi dan di organisir dalam bentuk sajian data, kemudian disimpulkan dengan memaparkan peran guru sebagai fasilitator dalam mengasah penalaran matematika siswa.

Pengecekan keabsahan temuan Moeloeng (2012;327) menyebutkan bahwa "dalam penelitian diperlukan suatu teknik pemeriksaan keabsahan data". Sedangkan untuk memperoleh keabsahan temuan perlu diteliti kredibilitasnya dengan menggunakan langkahlangkah sebagai berikut:

a) Ketekunan pengamatan, yaitu mengadakan observasi secara terus menerus terhadap objek penelitian guna memahami gejala lebih mendalam terhadap berbagai aktifitas yang sedang berlangsung di lokasi penelitian.

b) Triangulasi, yaitu teknik pemeriksaan keabsahan data dengan memanfaatkan sesuatu dari luar data sebagai pengecek atau pembanding data.

c) Kecukupan referensi, yaitu faktor pendukung untuk membuktikan data yang telah ditemukan. Hal ini dilakukan dengan cara melengkapi data-data yang akan dikemukakan dengan dokumen autentik agar lebih dapat dipercaya. 
d) Tahap penelitian ini terdiri atas tiga tahap yaitu:

(1) Tahap Persiapan

Pada tahap ini dilakukan serangkaian kegiatan yaitu dengan cara mengangkat permasalahan yang akan diteliti secara terperinci, menentukan objek yang dijadikan lokasi penelitian dan merumuskan batasan penelitian agar penelitaian terfokus pada satu permasalahan.

(2) Tahap Pelaksanaan

Pada tahap ini dikumpulkan semua data-data yang diperlukan yaitu melakukan wawancara dengan siswa. Kemudian melakukan analisis secara rinci data yang menjadi hasil wawancara selanjutnya menyediakansegala perlengkapan yang menyangkut alat tulis-menulis untuk mendapatkan data yang valid dan informasi yang akurat. Setelah tahap tersebut dilakukan, maka diperoleh data yang kompleks yaitu peran guru sebagai fasilitator dalam mengasah penalaran matematika siswa.

(3) Tahap Akhir (simpulan)

Pada tahap ini penyajian data dalam penelitian dilakukan dengan teks yang bersifat deskriptif. Data dari hasil analisis tersebut kemudian diuraikan dan ditelaah untuk menentukan tingkat penalaran matematika siswa.

\section{HASIL DAN PEMBAHASAN}

\section{A. Paparan Data}

Adapun paparan data yang digunakan dalam penelitian ini adalah:

1. Data Tahap perencanaan Peran Guru Sebagai Fasilitator dalam Mengasah Kemampuan Menalar Matematika

Pada saat perencanaan proses pembelajaran berlangsung, guru mempersiapkan silabus dan Rencana pelaksanaan pembelajaran (RPP) agar kegiatan pembelajaran lebih mudah di paparkan ke siswa tentang materi pembelajaran matematika. Dapat dilihat dari data hasil dokumentasi dan wawancara sebagai berikut:

\section{a. Data Dokumentasi}

Dari hasil dokumentasi dilihat dari RPP yang dirancang oleh guru kelas IV-B pada pembelajaran menulis karangan dengan media gambar berseri adalah sebagai berikut: "Berdasarkan hasil analisa RPP yang telah dirancang oleh guru kelas IV-B, menunjukan bahwa guru tidak mencantumkan penalaran matematika dalam RPP maupun silabus, tetapi guru tersebut tetap menerapkan proses pembelajaran yang bersifat penalaran matematika."

\section{b. Data Wawancara}

Dari Hasil wawancara dengan guru kelas IV-B dalam proses pembelajaran penalaran matematika, guru telah mempersiapkan Silabus dan RPP agar tujuan pembelajaran menjadi lebih terarah. "Penting bagi guru menyiapkan Silabus dan RPP sebelum proses pembelajaran berlangsung".

Pada saat menjelaskan materi pembelajaran guru hanya menggunakan dua metode demostrasi dan penugasan pada saat simulasi pembelajaran. "Lebih senang menggunakan metode ini, Dan sangat cocok untuk pembelajaran penalaran matematika”.

\section{Data Tahap Pelaksanaan Peran Guru Sebagai Fasilitator dalam Mengasah Kemampuan Menalar Matematika}

Pada saat pelaksanaan pembelajaran menulis karangan dengan media gambar berseri dilihat dari langkah-langkah pembelajarannya. Guru pada sa'at proses pembelajaran berlangsung melalui teknik observasi dan wawancara. 
a. Data Hasil Observasi

Dari hasil observasi guru dan siswa pada saat proses pembelajaran berlangsung adalah sebagai berikut: "Berdasarkan hasil pengamatan bahwa guru dalam mempersiapkan media pembelajaran dengan tujuan pembelajaran, terlihat dari aspek observasi guru menyediakan gambar yang di ambil dari buku atau dari internet, sedangkan aspek yang lainya terlihat guru sangat baik dalam meberikan kesempatan pada siswa untuk memperhatika gambar dan guru memberikan kesempatan siswa untuk berdiskusi, perangkat selanjutnya guru mulai menjelaskan materi sesuai dengan tujuan pembelajaran yang ingin dicapai dan memberikan tugas pada siswa untuk membuat kerangka karangan".

Berdasarkan hasil pengamatan bahwa siswa kurang disiplin karena hanya sebagian siswa yang patuh dan taat dalam peraturan dalam kelas dan juga terlihat siswa kurang siap dalam menerima pembelajaran diakibatkan masih ada siswa yang bermain sendiri, sehingga tidak siap menerima pembelajaran. Berdasarkan hasil pengamatan terlihat siswa dalam memperhatikan gambar sangat baik juga berdiskusi dengan teman sebangkunya terlihat siswa fokus dengan temanya dan kemampuan siswa dalam menalar yaitu cukup baik terlihat dari aspek observasi siswa.

b. Data Hasil Wawancara

Dari hasil wawancara guru dan siswa pada saat proses pembelajaran berlangsung konteks masalah guru tidak mempersiapkan fasilitas dengan baik dengan tujuan pembelajaran adalah sebagai berikut: "Guru hanya mengandalkan satu buku". Sedangkan dari aspek lainya guru sudah sangat baik dalam menjelaskan materi sesuai dengan tujuan pembelajaran dan memberikan kesempatan siswa untuk menganalis angka dengan baik untuk menalar. "Dalam proses pembelajaran berlangsung berjalan dengan baik dalam kelas dilihat dari aspek guru". Kemudian dari konteks masalah siswa pada saat proses pembelajaran berlangsung dari hasil wawancara siswa adalah sebagai berikut: "Kurangnya kedisiplin siswa dalam kepatuhan di kelas dalam proses pembelajaran dan kurang siap dalam menerima pembelajaran hanya tiga atau lima orang siswa tetapi keaktifan siswa dalam memperhatikan penjelasan guru dan kemampuan siswa dalam berdiskusi juga kemampuan siswa berdasarkan pengalaman terlihat cukup baik".

Dari data tersebut dapat disimpulkan bahwa pembelajaran matematika dengan menalar deduktif di kelas IV-B berjalan dengan baik, walaupun hanya sebagian siswa kurang disiplin maupun kesiapan menerima pembelajaran masih kurang.

\section{Data Tahap Evaluasi Peran Guru Sebagai Fasilitator dalam Mengasah Penalaran Matematika}

Evaluasi dalam pembelajaraan matematika dengan penalaran deduktif adalah evaluasi nontes yaitu wawancara dan pengamatan dalam proses pembelajaran berlangsung

\section{a. Data Dokumentasi}

Guru memberikan tugas pada siswa untuk mengerjakan sebuah soal dengan menggunakan media gambar adalah sebagai berikut: "Guru senang siswa dapat menerima adanya media gambar dalam pembelajaran penalaran matematika". Sedangkan kan siswa merasa termotivasi belajar mereka dengan adanya media gambar dalam pembelajaran menalar matematika. Dari data di atas dapat disimpulkan bahwa media gambar sudah diterima baik oleh siswa, dilihat dari antusias siswa dalam mengerjakan tugas yang diberikan guru. 


\section{b. Data Hasil Wawancara}

Berdasarkan hasil wawancara yang dilakukan peneliti pada guru kelas dan siswa adalah sebagai berikut: "Penerapan media gambar berjalan dengan baik di kelas IV-B, karena siswa merasa termotivasi belajar dalam hal menalar matematika. Guru "E" mengatakan saya senang melihat perubahan dari siswa saya sudah 2 tahun saya mengajar di kelas IV-B. dengan jadwal mata pelajaran matematika penilaian dengan cara memberikan soal dan penugasan. Guru berharap pada siswa agar tidak selalu bosan dan jenuh untuk menuangkan ide/ gagasan mereka".

Sedangkan sumber hasil wawancara dengan beberapa siswa seperti AL Dan AN kelas IV-B menggungkapkan bahwa: "Saya senang sekali belajar matematika dengan menggunakan media gambar, karena saya bisa menghadirkan ide/ gagasan yang saya miliki ke dalam bentuk berpikir, saya berharap kepada guru agar selalu menggunakan media ini pada mata pelajaran menalar matematika berdasarkan pengalaman. "Sangat senang sekali dengan adanya media gambar akan memudahkan saya untuk mampu menalar angka matematika. Sebab saya suka sekali dengan belajar matematika karena saya bisa berfikir lebih kreatif."

Dari hasil data wawancara di atas, proses pembelajaran menalar matematika dengan media gambar sangat diterima baik oleh siswa dan juga dapat memotivasi siswa untuk giat belajar terutama menalar.

\section{B. Pembahasan}

Pada bagian ini akan dibahas yaitu: (1) Tahap perencanaan peran guru sebagai fasilitator dalam mengasah penalaran matematika, (2) Tahap pelaksaan peran guru sebagai fasilitator dalam mengasah penalaran matematika, (3) Tahap evaluasi peran guru sebagai fasilitator dalam mengasah penalaran matematika.

\section{Tahap Perencanaan Peran Guru Sebagai Fasilitator dalam Mengasah Penalaran Matematika}

Melakukan pengamatan pada siswa kelas IV-B pada tahap awal perencanaan guru dalam proses pebelajaran matematika harus mempersiapkan perangkat pembelajaran seperti Silabus dan RPP. Dengan adanya Silabus dan RPP tujuan perencancaan guru dalam proses belajar-mengajar menjadi lebih terarah. Kemendikbud (2013) menyatakan RPP merupakan suatu rencana kegiatan pembelajaran tatap muka untuk satu pertemuan atau lebih. Setelah menyiapkan Silabus dan RPP guru melakukan absensi pada siswa setelah melakukan absensi guru mulai menjelaskan materi yang akan diterapkan pada siswa materi pembelajaran mmatematika dalam hal menalar. Guru lebih senang menggunakan metode demonstrasi dan penugasan pada siswa karena metode ini sangat cocok diterapkan pada pembelajaran penalaran matematika.

Pada data (a) menunjukan adanya perencanaan pembelajaran menalar matematika dengan media gambar pada saat menjelaskan materi guru menggunakan metode demontrasi dan penugasan. Kalimat intinya adalah "Lebih senang menggunakan metode ini. Dan sangat cocok untuk pembelajaran penalaran matematika". Kalimat ini menunjukan bahwa guru hanya menggunakan dua metode ini. Supriyatna (2007:211) menyatakan bahwa metode pengajaran adalah suatu cara yang digunakan untuk memberikan kesempatan selua-luasnya kepada siswa dalam belajar.

Pada data (b) Menunjukan adanya data hasil dokumentasi ananlisis RPP yang dirancang oleh guru. Kalimat intinya "Guru tidak mencantumkan adanya media gambar". Uraian ini menunjukan bahwa guru kurang bijak dalam membuat RPP karena tidak sesui dengan tujuan yang diharapkan. Hal ini bertentangan dengan harapan Yulaelawati (2004: 
123) menjelaskan bahwa "pengertian RPP adalah seperangkat pelaksanaan pengaturan pembelajaran dan penilaian yang dibuat untuk sistem yang mengandung semua komponen memiliki hubungan dengan tujuan menguasai kompetensi dasar".

Berdasarkan beberapa data tahap perencanaan pembelajaran menulis karangan dengan media gambar berseri dikemukan di atas dapat disimpulkan bahwa pada tahap perencanaan guru menyiapkan silabus dan RPP tetapi tidak mencantumkan adanya media gambar dan hanya menggunakan dua metode pembelajaran.

\section{Tahap Pelaksanaan Peran Guru Sebagai Fasilitator dalam Mengasah Penalaran Matematika}

Dalam pelaksanaan pembelajaran menalar deduktif dengan media gambar, berdasarkan hasil pengamatan observasi bahwa guru sudah baik dalam melaksanakan kegiatan proses pembelajaran berlangsung, seperti $1+4=5$ dan $2+3=5$ guru menjelaskan perlahan agar siswa dapat memahami kemudian dapat menyimpulkan, walaupun hanya empat atau tujuh orang siswa kurang disiplinan dalam kelas kurang baik, dan kesiapan siswa dalam menerima pembelajaran kurang baik karena masih ada siswa yang bermain sendiri tetapi keaktifan siswa dalam memperhatikan gambar, kemampuan dalam bersdiskusi juga kemampuan dalam menalar matematika sudah cukup baik. Hadojo (1998: 24) menyatakan bahwa "matematika merupakn ide-ide abstrak yang diberisimbol-simbol itu tersusun secara hirarkis dan penalarannya deduktif, sehingga belajar matematika itu merupakan kegiatan mental yang tinggi".

Pada data (c) dengan kode "O/G/04.01/2017". menunjukan bahwa pada tahap pelaksanaan pembelajaran menalar matematika dengan media gambar. Guru mempersiapkan gambar-gambar yang sesuai dengan tujuan pembelajaran. Kalimat intinya "Guru menyediakan gambar yang diambil dari buku atau yang didapat dari referensi sepertri di internet". Ungkapan tersebut menunjukkan guru tersebut kreatif dan menunjukkan perannya sebagai fasilitator dalam proses pembelajaran.

Pada tahap (d) Menunjukan bahwa pada tahap pelaksanaan pembelajaran menalar matematika dengan media gambar. kalimat intinya "Kurangnya kedisplinan siswa dalam kepatuhan pada saat proses pembelajaran". Maksud peryataan ini bahwa siswa kurang disiplin pada saat proses pembelajaran berlangsung dalam kelas. Hal ini tidak sejalan dengan ungkapan Sanjaya (2005: 9) disiplin adalah "hal yang sangat diperlukan bagi setiap siswa, dengan adanya disiplin dalam pembelajaran, tujuan pendidikan akan lebih mudah tercapai". Berdasarkan tahap pelaksanaan di atas dapat disimpulkan bahwa siswa terlihat tidak disiplin pada saat proses pembelajaran berlangsung.

\section{Tahap Evaluasi Peran Guru Sebagai Fasilitator dalam Mengasah Penalaran Matematika}

Evaluasi yang dilakukan guru dalam proses pembelajaran menalar matematika dengan media gambar adalah evaluasi nontes yaitu wawancara dan pengamatan. Pada wawancara dan pengamatan terlihat siswa senang dan menerima adanya media gambar dalam pembelajaran menalar matematika. Pada tahapan evaluasi terlihat siswa antusias menerima media gambar karena media ini dapat memotivasi mereka dalam proses belajarnya terutama yang berkaitan dengan hal menalar. Arikunto, (2003:4) mengungkapkan bahwa evaluasi adalah serangkaian kegiatan yang ditunjuk untuk mengukur keberhasilan program pendidikan.

Pada data (e) menunjukan bahwa pada tahap evaluasi pembelajaran matematika dengan media gambar dengan evaluasi nontes dari hasil wawancara dan pengamatan. 
Kalimat intinya "Penerapan media gambar berjalan dengan baik di kelas IV-B". Uraian ini menunjukan bahwa media gambar dapat memotivasi siswa dalam proses pembelajaran dalam hal menalar. Artinya peran guru sebagai fasilitator sudah terlaksana dengan baik. Bertentangan dengan apa yang dikatakan oleh Wijaya (2014) "Dalam hubungan yang bersifat "top-down", guru seringkali diposisikan sebagai "atasan" yang cenderung bersifat otoriter, sarat komando, instruksi bergaya birokrat, bahkan pawing".

Pada data (f) Menunjukan bahwa pada tahap evaluasi penalaran matematika dengan media gambar, dengan evaluasi hasil wawancara dan pengamatan. Kalimat intinya "Sangat senang sekali dengan adanya media gambar". Hal ini menunjukan bahwa media gambar sangat membantu siswa dalam memecahkan masalah. Susan (2010: 2) menyatakan bahwa dalam pembelajaran matematika kemampuan menalar dan memecahkan maslah memiliki peran penting yaitu kekuatan sentral bagi siswa dalam mengidentifikasi masalah dalam matematika.

Berdasarkan tahap evaluasi pembelajaran menalar matematika dengan media gambar dengan evaluasi nontes dari hasil wawancara dan pengamatan bahwa siswa senang dan bias menerima adanya media gambar dalam pembelajaran menalar matematika.

\section{SIMPULAN DAN SARAN}

\section{A. Simpulan}

Pada proses perencanaan pembelajaran sangat penting bagi guru atau pendidik dalam menyiapkan perangkat pembelajaran seperti silabus dan RPP agar proses pembelajaran bisa terarah dengan baik. Sedangkan dalam proses pelaksanaan guru sebagai fasilitator sudah baik dalam memfasilitasi siswa. Dan dilhat dari kemauan siswa dalam mengasah penalaran deduktif meningkat dan siswa meminati kegiatan pembelajaran tersebut. Peran guru sebagai fasilitator dalam pembelajaran matematika di SD Negeri 29 Dompu memiliki peran penting dalam mengoptimalkan proses pembelajaran di Kelas IV-B. Peran guru sebagai fasilitator untuk meningkatkan daya penalaran matematika agar meningkatkan rasa percaya diri pada siswa, memotivasi, menumbuhkan keingintahuan, dan meningkatkan minat belajar pada siswa terhadap penalaran contoh $3+5=8$, jadi siswa menalar bahwa angka ganjil jika dijumlahkan dengan angka ganjil yang berbeda maka menghasilkan angka genap.

\section{B. Saran}

Berdasarkan kesimpulan di atas maka penulis memberikan dan menyadari masih banyak kekurangan sehingga saya menyarankan beberapa hal sebagai berikut:

1. Kepada peneliti selanjutnya disarankan agar penelitian ini dapat dimanfaatkan sebagai acuan dalam melakukan penelitian selanjutnya.

2. Untuk dijadikan informan guru agar dapat menjadi fasilitator yang digemari siswa.

\section{DAFTAR RUJUKAN}

Angga Putra, \& Ija Srirahmawati. (2020). Korelasi antara Kondisi Lingkungan Keluarga Terhadap Kepatuhan Siswa Dalam Melaksanakan Tata Tertib Sekolah (Studi kasus pada siswa Sekolah Dasar). Ainara Journal (Jurnal Penelitian Dan PKM Bidang Ilmu Pendidikan), 1(2), 39-43. https://doi.org/10.1234567/ainarajournal.v1i2.12

Arifin, Fathirma'ruf, \& Ilyas Yasin. (2020). Efektivitas Belajar Al-Qur'an Dengan menggunakan Aplikasi Hijaiyah Berbasis Budaya Lokal "Nggahi Mbojo" (Bahasa Bima) Pada Lansia di Kabupaten Dompu.Ainara Journal Uurnal Penelitian Dan PKM Bidang Ilmu Pendidikan), 1(1), 24-30. https://doi.org/10.1234567/ainarajournal.v1i1.10

Ariyanto, Metta. 2016. peningkatan hasil belajar IPA materi kenampakan rupa bumi menggunakan model SCRAMBLE, jurnal pendidikan dasar: III (2): 134- 140 
Arikunto. 2006. Prosedur Penelitian Suatu Pendekatan Praktek. Jakarta: Rineka Cipta.

Asmedy. (2020). Perbandingan Hasil Belajar Connected Mathematics Project (CMP) dengan Pembelajaran Konvensional Pada Pokok Bahasan Geometri. JIIP - Jurnal Ilmiah Ilmu Pendidikan, 3(1), 456-464. Retrieved from http://jiip.stkipyapisdompu.ac.id/jiip/index.php/JIIP/article/view/131

Eka Yulianti, \& Taufik. (2020). Studi Perbandingan Eksistensi Alam Pada Novel Tanah Baru Tanah Air Kedua Karya Nh. Dini Dan Sri Rinjani Karya Eva Nourma (Tinjauan Ekologi Sastra). Ainara Journal (Jurnal Penelitian Dan PKM Bidang Ilmu Pendidikan), 1(2), 44-55. https://doi.org/10.1234567/ainarajournal.v1i2.13

Esi, Purwaningsih, E., \& Okianna. (2016). Peranan guru sebagai fasilitator dan motivator dalam meningkatkan hasil belajar di kelas XI SMK. Jurnal Pendidikan Dan Pembelajaran, 5(10), 1-14. http://jurnal.untan.ac.id/index.php/jpdpb/article/view/17132/14624

Fathirma'ruf, \& Muhammad Akbar. (2018). Perancangan Sistem Seleksi Penerimaan Calon Mahasiswa Baru Berbasis Website. JIIP - Jurnal Ilmiah Ilmu Pendidikan, 1(3), 102-106. Retrieved from http://jiip.stkipyapisdompu.ac.id/jiip/index.php/JIIP/article/view/28

Hakim. 2008. Dimensi-dimensi Administrasi Pendidikan di Sekolah. Jakarta: Bumi Aksara.

E. Mulyasa. (2013). Standar Kompetensi dan Sertifikasi Guru. Bandung: PT Remaja Rosda Karya.

Sugiyono.Esi, Purwaningsih, E., \& Okianna. (2016). Peranan guru sebagai fasilitator dan motivator dalam meningkatkan hasil belajar di kelas XI SMK. Jurnal Pendidikan Dan Pembelajaran, 5(10), 1-14. http://jurnal.untan.ac.id/index.php/jpdpb/article/view/17132/14624

Pamungkas, A. S., \& Yuhana, Y. (2016). Pengembangan Bahan Ajar Untuk Meningkatkan Kemampuan Bernalar Matematis Siswa. Jppm, 9(2), 177-182.

Sugiyono.2010. Statistik untuk Penelitian. Bandung: Alfabeta.

Sukmadinata, Nana Syaodih. 2008. Metode Penelitian Pendidikan. Bandung: Remaja Rosda Karya.

Pamungkas, A. S., \& Yuhana, Y. (2016). Pengembangan Bahan Ajar Untuk Meningkatkan Kemampuan Bernalar Matematis Siswa. Jppm, 9(2), 177-182.

Wijaya, dkk. 2014. Kemampuan Dasar Guru Dalam Proses Belajar Mengajar. Bandung: PT Remaja Rosdakarya. 